\title{
WAIVER OF ATTORNEY-CLIENT PRIVILEGE ON INTER-ATTORNEY EXCHANGE OF INFORMATION
}

Ir is often advantageous for attorneys of persons with a community of interest in litigation or in business transactions to exchange information. Such interchange is frequently necessary, for example, to enable proper appraisal of the conspiratorial acts often alleged in antitrust suits. ${ }^{1}$ Lawyers may hesitate to pool information freely, however, fearing that it might cause loss of immunity for material ordinarily privileged from either evidentiary use or pretrial discovery. ${ }^{2}$ Such material falls into two classes: 1) a lawyer's "work product," protected from pre-trial discovery unless "good cause" is demonstrated $; 3$ 2) confidential communications from a client to his attorney, pro-

1. See, e.g., communication to the Yale LAw Journal from Mathias F. Correa, of Cahill, Gordon, Reindel \& Ohl, New York, dated April 20, 1954, in Yale Law Library. Exchange of information is also often advantageous in mass tort actions, stuch as Penn. R.R. v. United States, 111 F. Supp. 80 (D.N.J. 1953) (railroad explosion causing damage to approximately 9,000 persons). See communication to the Yale LAw Jounnal from Joseph Keane, of Milton, McNulty \& Augelli of Jersey City, N.J., dated April 14, 1954, in Yale Law Library. And a "Working Committee" of 7 lawyers was formed to handle the trial of 308 suits arising from the famous Texas City harbor explosions. Sce In re Texas City Disaster Litigation, 197 F.2d 771, 773 (5th Cir. 1952), and communication to the YALE LAw Journal from Vernon Elledge, of Elledge, Urban, Elledge \& Bruce of Houston, Texas, dated April 26, 1954, in Yale Law Library.

2. It is apparent that fear of waiving these privileges may result in withholding information. See communication to the Yale Law Journal from Roy W. McDonald, of Donovan, Leisure, Newton \& Irvine, New York, dated April 30, 1954, in Yale Law Library. And the question of whether or not the interchange of data constitutes a waiver often arises, particularly in antitrust litigation. See communications to the YALE LAW Journal from Roy W. McDonald, supra, and from Mathias F. Correa, of Cahill, Gordon, Reindel \& Ohl, New York, dated April 20, 1954, in Yale Law Library. A memorandum dealing with this question was prepared by the cooperating attorneys in the recent case of United States v. Morgan, 118 F. Supp. 62 (S.D.N.Y. 1953). See communications to the Yale Law Journal from Herman A. Heydt, Jr., of Breed, Abbott \& Morgan, New York, dated April 27, 1954, and from Walter K. Earle, of Shearman, Sterling \& Wright, New York, dated May 26, 1954, in Yale Law Library. However, the question was apparently of minor importance in that case because there were few documents that might have been privileged. See communication to the Yale Law JourNal from Edward R. Wardwell, of Davis, Polk, Wardwell, Sunderland \& Kiendl, New York, dated April 7, 1954, and from Roy W. McDonald, sttpra, in Yale Law Library.

3. Hickman v. Taylor, 329 U.S. 495, 511 (1947), defines the "work product" of an attorney as that which is reflected in "interviews, statements, memoranda, correspondence, briefs, mental impressions, personal beliefs, and countless other tangible and intangible ways." The Hickman case held that, even though this "work product" is not accorded the absolute protection of the attorney-client privilege, its revelation cannot be secured by deposition under FED. R. Crv. P. 26 without showing "good cause." See note 4 infra. This qualified privilege is also given an attorney's "work product" under FED. R. Civ. P. 34, which authorizes the pre-trial production of documents upon a demonstration of "good cause."

A number of states have accepted the Hickman rule. See, e.g., Miami Transit Co. v. 
tected absolutely from both pre-trial discovery and the lawyer's testimonial disclosure. ${ }^{4}$ If one party or his attorney reveals either type of data to another party or his attorney, the privilege ordinarily accorded this material could be held waived because of disclosure to a third person. An additional ground for suspending the confidential communication privilege could be the absence of the necessary attorney-client relation between the declarant and the other party or his attorney. ${ }^{\circ}$ And even if the attorney-client privilege were held to preclude forcing such other person or his attorney to reveal confidential communications disclosed to him, ${ }^{7}$ it is uncertain whether the privilege would apply if that person voluntarily testified against or sued the declarant.8

Hurns, 46 So.2d 390 (Fla. 1950) ; State v. Caruthers, 360 11o. 8, 12, 226 S.W.2d 711, 713 (1950) ; Schwartz v. Public Service Coordinated Transport, of A.2d 477, 480-1 (N.J. Co. Ct. 1949).

4. Complete immunity from pre-trial discovery of a client's confidential communications to his attorney is provided in the federal courts by the requirement of FED. $R . C r$. P. 26 and 33 that information sought through deposition or interrogatory not be "privileged." E.g., Rowe v. Union Central Life Ins. Co., 1 Mfoone, F. R. SEv. 370 (D.D.C. 1939) ; Grauer v. Schenley Products Inc, 26 F. Supp. 768 (S.D.N.Y. 1938). See Mrov3E, Fenzral Practice $\$ 26.22$, p. 1085 (2d ed. 1951).

For a complete survey of the development and application of the attorney-client privilege as an absolute bar to testimonial disclosure, see 8 WIGsrose, Entratrce $\$ 3$ 2200-2320 (3d ed. 1940) (hereinafter cited as WIGMTORE).

5. Generally, if the client makes the statement either directly to a third person or to his attorney in the presence of a third person, he is deemed to have vaived the privilege on the theory that he could not have intended his statement to be confidential. E.g., Sharon v. Sharon, 79 Cal. 633, 22 Pac. 26 (1859) ; Crawford v. Raible, 206 Iowa 732, 221 N.W. 474 (1928) ; In re Quick's Estate, 161 Wash. 537, 297 Pac. 198 (1931). And if the client is held to have impliedly authorized his attorney's disclosure of the information to a third person, the privilege is also waived. Himmelfarb v. United States, 175 F.2d 924 (9th Cir. 1949). Further, it appears that an attorney will generally be held to have authority to disclose privileged data to an adverse party. Reg. v. Downer, 14 Co: Cr. Cas. 486,489 (1880); Lloyd v. 11ostyn, 2 Dowl.P.C.N.S. 476 (1842) scinblc; \& Wigsese $\$ 2325$. Thus, a court would probably hold that such disclosure to a cooperating party or to his attorney was also authorized by the client.

6. Since the privilege is designed to protect only the relation between the client and his own attorney, immunity is generally restricted to communications between such pessons. E.g., Watson v. Detroit Free Press, 248 Mich. 237, 226 N.W. 854 (1929); State v. Davenport, 227 N.C. 475,498 , 42 S.E.2d 686, 703 (1947).

7. Although the privilege generally immunizes only testimony by the clicnt or the attorney, see 8 WIGMToRe $\$ 2324$, it also applies to testimeny of a third person if he is classified as an "agent" of either the client or the attorney while transmitting, receiving, or overhearing the communication. E.g., Landsberger v. Gorham, 5 Cal. 450 (1855) (attorney's clerk); In re Busse's Estate, 332 Ill. App. 258, 75 N.E.2d 36 (1947) (servant of client) ; Maas v. Bloch, 7 Ind. 202 (1855) (interpreter); Hollien v. Kaye, 194 Mise. \$21, S7 N.Y.S.2d 782 (Sup. Ct. 1949) (client's insurance company). It is liliely that a court which holds that disclosure to another party or to his attorney does not constitute waiver will also prohibit forcing testimonial disclosure by such a third person by categorizing him as an "agent." For if the third person could be required to divulge the informstion, it would be purposeless to hold that there had been no waiver.

S. Although the privilege belongs to the communicating client, see 8 Wrasons $\$ 2321$, he might be held to have assumed the risk of voluntary revelation by formerly cooperating parties. See text at notes $40-3$ infra. 
Despite a paucity of cases, it appears safe to conclude that the exchange of "work product" among counsel for parties with a common interest will not subject that data to pre-trial discovery. The decisions reasonably suggest that a mere showing of such interchange does not establish the "good cause" necessary to revoke the qualified privilege of this material." "Good cause" has always consisted of a demonstrated hardship upon the party seeking discovery. ${ }^{10}$ Thus, if a witness becomes unavailable, a party may secure his recorded answers to the questioning of an adverse party's lawyer, even though they may reveal the "mental processes" of the interrogating attorney.11 The interchange of information among cooperating lawyers, however, by itself imposes no hardship upon another person. ${ }^{12}$

The few cases relevant to the more complicated question of the attorneyclient privilege indicate that persons conducting a "joint defense" may pool information without waiving this privilege. ${ }^{13}$ But these decisions leave unsettled the meaning of "joint defense" as well as the rights of co-plaintiffs, persons with more limited common interests in litigation, and co-adventurers in business transactions. ${ }^{14}$ Only two American holdings are based on the

9. Leonia Amusement Corp. v. Loew's, Inc., 13 F.R.D. 438 (S.D.N.Y. 1952) ; Smith v. Bentley, 9 F.R.D. 489 (S.D.N.Y. 1949). See Byers Theatres, Inc. v. Murphy, 1 F.R.D. 286, 289 (W.D. Va. 1940).

10. E.g., Dellameo v. Great Lakes S.S. Co., 9 F.R.D. 77 (N.D. Ohio 1949) (production of hospital records denied because plaintiff could obtain them by exercising reasonable diligence); Blair v. Travelers Ins. Co., 9 F.R.D. 99 (W.D. Mo. 1949) (same). See, generally, Taine, Discovery of Trial Preparations in the Federal Courts, 50 Cot. L. Rev. 1026 (1950) ; Note, 62 Harv. L. Rev. 269 (1949).

11. See Hickman v. Taylor, 329 U.S. 495, 511 (1947) ; Cleary Bros. v. Christie Scow Corp., 176 F.2d 370, 372 (2d Cir. 1949). Cf. Hoffman v. Chesapeake \& O. Ry., 7 F.R.D. 574, 575 (N.D. Ohio 1947).

12. The argument for waiver would probably be based upon the contention that the information exchanged is inaccessible to the adverse party. Acceptance of this as demonstrating "good cause," however, would completely eliminate the qualified privilege of "work product," because the same argument can always be made. Hence something further should be required before the privilege is denied.

13. Schmitt v. Emery, 211 Minn. 547, 2 N.W.2d 413 (1942); Cahoon v. Commonwealth, 62 Va. (21 Gratt.) 822 (1871). See Smale v. United States, 3 F.2d 101, 102 (7th Cir. 1924 (no "joint defense" between persons jointly indicted for conspiracy to influence jurors because trial preparation was "separate and distinct"); Leonia Amusement Co. v. Loew's, Inc., 13 F.R.D. 438, 441 (S.D.N.Y. 1953) (privilege may apply in cooperative antitrust defense); Vance v. State, 190 Tenn. 521, 529-30, 230 S.W.2d 987, 990-1, cert. denied, 339 U.S. 988 (1950) (no intent to conduct a "joint defense" between attorneys of co-defendants) ; State v. Hodgdon, 89 Vt. 148, 149, 94 Atl. 301, 301-2 (1915) (no "common defense" among persons jointly indicted for murder) semble.

14. There is reason to believe that the counsel of persons engaged in a cooperative business venture may not be able to exchange information without waiving the attorneyclient privilege. Harris v. Daugherty, 74 Tex. 1, 11 S.W. 921 (1889), held that the attorney-client privilege did not protect statements made by a buyer during a purchase and sale conference with the seller and his attorney. Under the broader English rule, see note 15 infra, the absence of one of the conferees' attorneys was deemed irrelevant in similar circumstances. Rochefoucauld v. Boustead, 65 L.J. Ch. 794 (1896). 
"joint defense" rule, although it is supported by dicta in several cases. ${ }^{15}$ Cahoon v. Commona'ealth ${ }^{10}$ involved a joint forgery indictment of $\mathrm{A}, \mathrm{B}$, and C. Upon the separate trial of $A$, the court held that B's attorney could not testify to admissions made by $A$ during a joint consultation of the co-defendants and their attorneys. And in Schmitt $v$. Emery, ${ }^{17}$ a personal injury suit against the drivers of two cars, the court refused to admit in evidence a defendant's written statement which his attorney had given to the other defendant's lawyer. ${ }^{18}$

Because of this lack of precedent, a court now has great latitude in interpreting the "joint defense" principle. Even if the rule were extended by" analogy to protect interchange of information among co-plaintifis' attorneys, it might still be cast in any of four progressively broader forms. Thus, the privilege could be restricted to cases where the result of litigation affects all defendants or plaintiffs identically, as in class actions. ${ }^{10}$ Or protection might be extended whenever there is community of interest in at least one major issue of a case, such as a plaintiff's contributory negligence. $20 \mathrm{~A}$ third position would enforce the privilege where there is any joint interest in litigation, even if only in a minor issue such as the exclusion of evidence. ${ }^{21}$ The broadest definition of the "joint defense" rule would protect all persons with a common interest in joint consultation, even if no litigation was in prospect. 2

One basis for predicting the future development of the "joint defense" doctrine is the weakness of its policy rationale. Some courts have erroneously

15. See note 13 supra.

The only two relevant English cases project the privilege beyond the "joint defense" theory. Entoven v. Cobb, 2 D.G.M. \& G. 632, 42 Eng. Rep. 1019 (Ch. 1852), involved privileged data exchanged by attorneys of three holders of similar bonds. Although they were not jointly suing their creditor, they had a common interest in proving the validity of each other's bonds. Therefore the court held that the exchange of data among them could not bring an inference of intent to waive the privilege. Rochefoucauld $v$. Boustead, 65 L.J. Ch. 794, (1S96), extends the privilege to statements made during a conference concerned with business and not litigation.

16. $62 \mathrm{Va}$. (21 Gratt) $\$ 22$ (1S71).

17. 211 Minn. 547, 2 N.W.2d 413 (1942).

18. Although the court stated that the deiendants had "substantially the same cause", their community of interest was less than that of the defendants juintly indietcd for lourglary in the Calooon case. In the Sclmaitt case, a judgment against une defenuant vould be completely unrelated to the issue of the other's liability. And active cooperation in this case was apparently limited to the exchange of one statement during preparation of a joint objection to the admission of evidence.

19. This category might also include criminal conspiracy cases, where it is quite probable that a conviction of one of the conspirators will presage conviction of all. Class actions would cover suits by or against corporate shareholders or stecliholders in unincorporated associations. See 3 MIO0ne, Feneral Prictice $\$ 23.08$.

20. This class would probably include mass turt actions where all phintiffs are jointly interested in proving the defendant's negligence, but where each has his own damage claim. See note 1 supra.

21. The Schomitt case would fall into this category. Sce note 18 suira.

22. This appears to be the English rule. See notes 14 and 15 supro. 
regarded this rule as simply a necessary extension of the ordinary attorneyclient privilege. ${ }^{23}$ A client's confidential communications to his attorney have traditionally been immunized in order to secure more adequate legal representation through inducing full disclosure. ${ }^{24}$ Since the privilege hampers the search for truth and often shelters the guilty, it has been strictly construed.25 Nevertheless, it is retained to encourage complete divulgence both by the person whose cause is partially just and by the client who mistakenly regards some of his actions as legally culpable. ${ }^{26}$ However, a court could reasonably conclude that the purpose of the privilege is adequately served once disclosture is made by a client to his own attorney. Enthusiasm for the "fox hunt" philosophy of litigation is waning, ${ }^{27}$ and the tactical advantage in an exchange of information among independently hired attorneys might be deemed of insufficient social importance to justify an extension of the privilege. The probability of judicial refusal to apply the privilege would vary inversely with the importance of pooling information, which in turn would depend upon the degree of community of interest among the parties.

These policy considerations are counterbalanced by the fact that restrictions of the privilege in information pooling cases could be largely circumvented by common hiring of attorneys. ${ }^{28}$ There is generally no waiver of the attorneyclient privilege when information is exchanged among attorneys jointly representing several clients. ${ }^{20}$ And a lawyer probably qualifies as a joint attorney

23. See Schmitt v. Emery, 211 Minn. 547, 554, 2 N.W.2d 413, 417 (1942) ; Cahoon v. Commonwealth, 62 Va. (21 Gratt.) 822, 838-9 (1871).

24. See, e.g., Greenough v. Gaskell, 1 Myl. \& K. 98, 103 (1833) ; Anderson v. Bank, 2 Ch. D. 644,649 (1876) ; Hatton v. Robinson, 31 Mass. (14 Pick.) 416, 422 (1833); Wade v. Ridley, 87 Me. 368, 373, 32 At1. 975, 976 (1895) ; 8 WIGMoRE $\$ 2291$; 1 GREENLEAF, EVIDENCE $\$ 238$ (1854). Wigmore suggests that the privilege also serves the function of preventing an attorney from feeling a "sense of treachery", but grants that this factor is "somewhat speculative." See 8 WIGMoRe $\$ 2291$, p. 557. This cannot be a judicially accepted reason for retaining the privilege, however, because it would apply with equal force to confidential communications made to anyone.

25. See, e.g., In re Ruos, 159 Fed. 252 (E.D. Pa. 1908) (privilege restricted to information obtained directly from client) ; State v. Sterrett, 68 Iowa 76, 25 N.W. 936 (1885) (privilege inapplicable to testimony of third person who overheard communication to attorney); State v. Falsetta, 43 Wash. 159, 86 Pac. 168 (1906) (same).

26. See 8 WrgMore $§ 2291$, pp. 555-7.

27. The outstanding indication of this trend is the enactment and the increasingly liberal interpretation of the pre-trial discovery sections of the Federal Rules. Sce, c.l/., Hickman v. Taylor, 329 U.S. 495, 507 (1.947); Hoffman v. Palmer, 129 F.2d 976, 997 (2d Cir. 1942) ("But the reformers are surely right that 'unfairness' to a diligent lawyer is of no importance as against much-needed improvement in judicial ascertainment of the 'facts' of cases; the public interest in such ascertainment is paramount." Frank, J.). Sec, generally, Taine, Discovery of Trial Preparations in the Fedcral Courts, 50 CoL. L. Rev. 1026 (1950); Pike \& Willis, Federal Discovery in Operation, 7 U. of Cur. L. Rev. 297 (1940).

28. The Cahoon decision was greatly influenced by the fact that the clients could have jointly hired the attorneys and thus escaped the possibility of waiver. See Cahoon v. Commonwealth, 62 Va. (21 Gratt.) $822,841-2$ (1871).

29. E.g., Jahnke v. State, 68 Neb. 154, 94 N.W. 158 (1903); State v. Archulcta, 29 
if he is paid by the several parties. ${ }^{30}$ This arrangement is often utilized when the interests of plaintiffs or defendants coalesce perfectly or when a court directs consolidation of suits because of "a common question of law or fact."31 Where the concord of interests is less than complete, however, or where consolidation is impossible either because of state law or because the cases are being tried in different states, ${ }^{32}$ attorneys apparently prefer to represent their clients independently, confining their cooperation to the exchange of information. ${ }^{33}$ But if such inter-communication were held to destroy the attorneyclient privilege, lawyers could arrange to be hired jointly by all clients with common interests. The unwary attorney, however, might not think of this strategy. The law should not make waiver depend upon the adroitness of counsel.

Courts should compromise these conflicting interests by permitting pooling of information without waiver of the attorney-client privilege if the data exchanged are relevant to a common interest among the clients. This would limit the broadest application of the "joint defense" rule only by the requirement of relevancy. ${ }^{34}$ Since the joint attorney escape device can be used under

N.M. 25, 217 Pac. 619 (1923). The only limitation upon use of this escape device is the rule that the privilege is inapplicable in a subsequent suit between the joint consultants. Grifin v. Griffin, 125 I1l. 430, 17 N.E. 782 (1SSS); Jenlins v. Jenlins, 151 Neb. 113, 36 N.W.2d 637 (1949) ; Billias v. Panageotou, 193 Wash. 523, 76 P.2d 987 (1938). Contra: Hull v. Lyon, 27 Mo. 570 (1858). Where the interests of the parties are substantially identical, this rule would probably not hinder utilization of the joint attorney scheme.

30. Apparently the determining factor is a manifested intent to consult the attorngy as a common agent. Thus a lawyer may be a common attorney even though not paid by both parties. See Baldwin v. Commissioner, 125 F.2d 812 (9th Cir. 1942); Jabnlie :. State, 68 Neb. 154, 94 N.W. 158 (1903). And juint payment probably suficiently manifests the requisite intent. See Cahoon v. Commonwealth, 62 Va. (21 Gratt.) 822, 841-2 (1871).

31. FED. R. CIv. P. 42(a). A court has discretion to order consolidation under this rule. The joint attorney device was used after consolidation of the claims arising out of the Texas City Harbor explosions. See note 1 supra.

32. Actions pending before different courts cannot be consolidated under FEn. $\mathrm{R}$. Crr. P. 42(a). United States to use of N.Y. Plumbers Specialties Co. v. Silverburgh Construction Co., Inc., 10 F. Supp. 121 (E.D.N.Y. 1935); Schwartz v. Kauiman, 46 F. Supp. 318 (E.D.N.Y. 1940). And many states do not have the consolidation provisions of the Federal Rules. For a general discussion of limitations upon consolidation, sce 5 Mroose, Fedreal Practice $\$ 42.02$.

33. Some lawyers consider use of the joint attorney device highly desirable. See communications to the Yale LAw Joukxal from Vernon Elledge, of Elledge, Urian, Elledge \& Bruce, Houston, dated April 26, 1954, and from Ray G. Brown, attorney in Portland, Ore, dated April 2, 1954, in Yale Law Library. Others appear to view its practicality as severely limited by factors such as friendship and traditional representation. Sce communications to the Yale Law Jocknal from Roy W. AcDonald, of Donovan, Leisure, Newton \& Irvine, New York, dated April 30, 1954; from W. Graham Claytor, Jr., oi Covington \& Burling, Washington, dated April 5, 1954; and from A. C. Allen, of Allen \& Roberts, Portland, Ore., dated April 2, 1954, in Yale Law Library.

34. No definite relevancy rule applies to the attorney-elient privilege. Many cuturts hold that the client must believe that the communication relatcs to a matter upun whin 
any circumstances, the privilege should not be confined to those situations where the clients have a complete or substantial identity of interest. Still, policy considerations dictate greater restriction of the privilege in information pooling cases than in joint attorney situations. When several persons hire the same lawyer, all confidential communications to him must be privileged to insure expert scrutiny of all the facts. However, when several parties with common interests independently hire attorneys, disclosure to an expert is sufficiently guaranteed by protecting all confidential communications between each client and his own attorney. The more limited end of promoting effective cooperation among the lawyers can be served adequately by shielding interchange of only relevant material. ${ }^{35}$

The suggested rule might be conveniently cast in any of three doctrinal molds. The various clients and their attorneys could simply be excluded from the class of "third persons" whose presence judicially robs a communication of its confidentiality. ${ }^{36}$ Or courts might regard each lawyer as representing all clients in the area of their common interest. Relevant communications could then be protected by direct analogy to the joint attorney rule. And this might be modified by considering each lawyer an agent of his own client as well as an attorney of all other clients. Communications between lawyers would then be between a client's agent and one of his attorneys; and such confidential communications are privileged. ${ }^{37}$

The proposed extension of the privilege would have an uncertain effect upon a client to whom the confidential communications of other clients are revealed at a joint conference. ${ }^{38}$ While he probably could not be compelled

legal advice may be or is being sought. See, e.g., State v. Mewherter, 46 Iows 88, 94 (1877) ; Denunzio's Receiver v. Scholtz, 117 Ky. 182, 192, 77 S.W. 715, 716 (1903). But the relation may be quite tenuous. See, e.g., Aiken v. Kilburne, 27 Me. 252, 262 (1847); National Bank v. Delano, 177 Mass. 362, 365, 58 N.E. 1079, 1080 (1901). This liberal view is necessary to insure full disclosure to the attorney. See 8 Wigmore $\$ 2310$. However, since the social value gained by interchange of information among attorneys is substantially counterbalanced by the social interest in attaining truth, see text at notes $23-7$ supra, and since the imparter of the data will generally be a trained lawyer, it would be reasonable to impose a strict relevancy requirement on such exchanges. Where the client gives the information to a cooperating party's attorney, it would be possible to establish a presumption of relevancy.

35. The generality of this criterion should not bar its application. The question of relevancy is frequently decided during trials. An analogous use of the relevancy rule occurs in determining whether or not communications by a client's agent are within the scope of his agency. See Le Long v. Siebrecht, 196 App. Div, 74, 187 N.Y. Supp. 150 (1.921).

36. This rationale is used both where "agents" of the lawyer or client were present when the communication was made and where another party who has jointly hired the attorney was present. See cases cited notes 7 and 29 supra.

37. See note 7 supra.

38. Presumably the privilege would apply to a cooperating client whether he simply overhears the communications being made to one of the attorneys or whether the disclosure is made directly to him. Although the attorney-client privilege is generally restricted to statements made to an attorney, see note 6 supra, the classification of a person 
to disclose the confidential information, he might be permitted to divulge it if he voluntarily testified against or sued the maker of the communication. A similar situation arises when persons who jointly employed an attorney are opposing parties in a later lawsuit. The attorney-client privilege then does not apply either to the jointly hired attorney or to his former clients. ${ }^{39}$ This principle rests on the rationale that neither client would have intended to keep his communications to the lawyer confidential vis a vis the other. ${ }^{40}$ Identical reasoning in the pooling of information cases would conclude that, in a suit between formerly cooperating persons, the attorney-client privilege should not bar either the parties or the formally collaborating lawyers from testifying to exchanged confidential communications. And, by analogy, a person who voluntarily testifies against one of his former conferees should not be bound by the privilege. ${ }^{11}$ While dictum in the Schmitt case opposes this result, ${ }^{42}$ the Cahoon holding supports it. ${ }^{43}$ There the court allowed a defendant who had turned state's evidence to testify to an admission made by his co-defendant during a joint consultation among them and their attorneys.

The application of the proposed rule to lawyers is clear except where one of the previously cooperating parties is permitted to testify to another's confidential communication. Under any other circumstances none of the attorneys could testify to relevant confidential communications made to him or overheard by him at a joint conference.44 And the Cahoon case held that even

as an "agent" extends the protection to communications made to such a person. See note 7 supra. By analogy, categorization of a cooperating party as a non-disqualifying third person should immunize statements made directly to him at least to the estent that he could not be forced to disclose them.

39. See note 29 supra.

40. See cases cited note 29 supra. Thus, the formal rationale for this rule is one of intent. If actual intent were to govern, however, waiver would not generally result, since it is likely that clients in such situations never intend that the information should te used against them in litigation. The controlling reason for the rule is probably the judicial belief that full disclosure to a common attorney may be sufficiently promuted withiut applying the privilege in a later suit by the jointly consulting parties. In most eases, the expectations of the communicator probably do not include the contingency of suit by the other party.

41. There is support for applying the privilege in joint attorney cases to voluntary testimony by one of the formerly cooperating parties in a later criminal action, as distinguished from a later civil action where the witness is a parly. State v. Archuleta, 29 N.11. 25, 217 Pac. 619 (1923). Contra: Jahnle v. State, 68 Neb. 154, 94 N.W. 158 (1903). There appear to be no rational grounds for this distinction. The communicating party's intention to waive confidentiality in relation to the other party is the same whether the party testifies in a criminal or a civil action. And his reasonable expectations no more include the other person's bringing suit against him than that person's turning state's evidence.

42. Schmitt v. Emery, 211 Minn. 547, 554, 2 N.W.2d 413, 417 (1942).

43. Cahoon v. Commonwealth, 62 Va. (21 Gratt.) $\$ \cong 2$ (1871).

44. This would simply be the purpose and effect of holding that neither the attorneys nor their clients are third persons whose presence would destroy the privilege. See nute 38 stipra. 
when a person turning state's evidence is allowed to testify to admissions made by his co-defendant in a joint conference, the attorney-client privilege blocks refutation by the witness' former attorney unless it is waived by all former conferees, including the witness himself. ${ }^{45}$ Since the privilege should protect only the person making the confidential communication, ${ }^{40}$ his waiver alone should enable an attorney to reveal such information. ${ }^{47}$

Protecting the exchange of relevant information among parties with a common interest in the absence of declarant's voluntary waiver would neither unduly hamper the search for truth nor cause inequity to the client.

45. Cahoon v. Commonwealth, 62 Va. (21 Gratt.) 822 (1871).

46. See 8 WIGMORE $\$ 2321$ and cases cited therein.

47. The only justification for not permitting such testimony by the attorney would bo that the communication reflected in some way another confidential communication by a cooperating party. 